九州大学学術情報リポジトリ

Kyushu University Institutional Repository

\title{
A Rainfall Simulation Study of Soil Erodibility and Avai lable Nutrient Losses from Two Contrasting Soils in China
}

Fang, Qingqing

College of Water Sciences, Beijing Normal University, Engineering Research Center of Groundwater Pollution Control \& Remediation, Ministry of Education

Zhang, Lei

College of Resource and Environment, Qingdao Agricultural University

Sun, Haotian

Graduate School of Bioresource and Bioenvironmental Sciences, Kyushu University

Wang, Guoqiang

College of Water Sciences, Beijing Normal University, Engineering Research Center of Groundwater Pollution Control \& Remediation, Ministry of Education

他

https://doi.org/10.5109/1526322

出版情報：九州大学大学院農学研究院紀要. 60 (1)，pp. 235-242，2015-02-27. Faculty of Agriculture, Kyushu University

バージョン：

権利関係 : 


\title{
A Rainfall Simulation Study of Soil Erodibility and Available Nutrient Losses from Two Contrasting Soils in China
}

\author{
Qingqing FANG ${ }^{1}$, Lei ZHANG ${ }^{2}$, Haotian SUN $^{3}$, Guoqiang WANG ${ }^{1 *}$, \\ Zongxue $\mathrm{XU}^{1}$ and Kyoichi OTSUKI
}

\author{
Laboratory of Forest Ecosystem Management, Division of Forest Sciences, \\ Department of Agro-Environmental Sciences, Faculty of Agriculture, \\ Kyushu University, Sasaguri, Fukuoka 811-2415, Japan \\ (Received October 31, 2014 and accepted November 14, 2014)
}

\begin{abstract}
The relationship between soil erodibility and sediment-bound available nitrogen (AN) and available phosphorus (AP) losses were rarely mentioned in previous studies. The experiments were carried out using a soil flume and a rainfall simulator to evaluate the relationship. The impacts of rainfall intensity and slope on sediment-bound AN and AP losses and the relationship between soil erodibility and soil properties were also studied. Eight simulated rainfalls were applied on the flumes with different conditions (two rainfall intensities, two slopes) from two contrasting soil of China (Burozems and Cinnamon) with two replicates. The soil erodibility of Cinnamon is much higher than that of Burozems. The higher soil erodibility of the Cinnamon soil resulting in greater runoff, soil loss and sediment-bound AN and AP losses. The sediment yield rate significantly influenced the sediment-bound AN and AP losses. The soil erodibility also significantly influenced the sediment-bound AN and AP losses based on Principal Components Analysis (PCA) result. The results of PCA also showed that other soil properties (organic matter, bulk density and cation exchange capacity) were related to soil erodibility. Increasing rainfall intensity and slope resulted in increasing runoff, sediment and sediment-bound AN and AP losses for both soils. Our study showed a good evaluation with the role of soil erodibility related to sediment-bound AN and AP losses and other soil erosion parameters.
\end{abstract}

Key words: nutrient loss, rainfall simulation, soil erodibility, soil properties

\section{INTRODUCTION}

Soil loss through erosion is one of the most serious environmental concerns as it removes soil nutrients. Diffuse nutrient loading from agricultural areas has been pointed out as one of the main threats to the ecological condition of the Chinese aquatic environment (Wang et al., 2009). The reported nutrient enrichment ratios of eroded soils have been up to 5.7 (Coleman et al., 1990). Nutrient losses by erosion are mainly associated with the clay and organic fractions of the soil which are removed first (Berghe and Boodt, 1979). Nutrient losses also occur during runoff and sediment yielding and result in eutrophication (Morgan, 2005; Zhang et al., 2011).

Many previous studies investigated the runoff, sediment and nutrients loss in the soil erosion process and the related contributing factors such as rainfall intensity, slope, vegetation coverage, and land use at field or laboratory scale (Pan and Shangguan, 2006; Zhang et al., 2011; Gilley et al.,2012). But few studies have been concentrated on the available nutrient losses, which could be directly absorbed by plant. The rate of soil erosion by rainfall depends on factors such as rainfall depth and energy, runoff depth and velocity, land slope, and soil

1 College of Water Sciences, Beijing Normal University, Engineering Research Center of Groundwater Pollution Control \& Remediation, Ministry of Education, Beijing 100875, China.

2 College of Resource and Environment, Qingdao Agricultural University, Qingdao 266109, China.

Graduate School of Bioresource and Bioenvironmental Sciences, Kyushu University, Fukuoka 811-2415, Japan.

* Corresponding author (E-mail: wanggq@bnu.edu.cn) erodibility which is the susceptibility of the land surface to erosive forces. Soil erodibility is often considered as a constant in the functional relationship between the erosion rate (dependent variable) and some rainfall-related independent variables (Sheridan et al., 2008). In the empirical Universal Soil Loss Equation (USLE), soil erodibility is estimated based on soil texture, organic matter content, structural group, and permeability class (Wischmeier and Smith, 1978). In the process-based Water Erosion Prediction Model (WEPP) (Flanagan and Nearing, 1995), the baseline interrill erodibility is calculated based on soil texture factors only (Alberts et al., 1995). But the above-mentioned models only quantify soil erodibility as a type of indicator for an average condition of a certain soil for a long time. However, soil erodibility is actually a dynamic process, because it is related to intrinsic soil properties changing during storm events, and to exogenic erosional forces varying in space and time (Wang et al., 2014). Several studies focus on the calculating soil erodibility for one event at laboratory scale and evaluated its role in soil erosion process.

Natural rainfall events are unpredictable and no rain events are identical in terms of variations during the storm, intensity, drop size distribution and kinetic energy (Meyer, 1988). On the other hand, rainfall simulation studies are more dependable: they are more rapid, efficient, cost effective, controllable and adaptable to study soil erosion events when compared to natural events. Therefore, field and laboratory rainfall simulation studies have been widely used to investigate soil erosion and nutrient losses (e.g., Bryan and De Ploey, 1983; BowyerBower and Burt, 1989; Morgan, 1995). Experiments in 
the laboratory enable an exploration of a large range of hydrologic conditions occurring at the plot and hillslope scale particularly during events with a strong spatial and temporal variability.

The objective of this study was to examine the relationship between soil erodibility and sediment-bound available nitrogen (AN) and available phosphorus (AP) losses. Available nutrient losses are followed by runoff and soil loss, and soil erodibility are related to changed soil properties after rainfall simulation. Therefore, the impact of slope and rainfall intensity on runoff, sediment and soil erodibility, and the relationship between soil erodibility and changed soil properties have been also studied.

\section{MATERIALS AND METHODS}

Laboratory rainfall simulation experiments were conducted to quantify a number of erosion related parameters under certain controlled conditions, such as soil erodibility and nutrient losses. In this study, the soil erodibility factor was generated from the laboratory rainfall simulation experiments. The experiments were carried out using a soil flume and a rainfall simulator.

\section{Soil Characteristics}

The two soils used in this study were Cinnamon soil and Burozems soil, which were taken from the field sites on the Experiment Station of Qingdao Agricultural University. They are important agricultural soils, distributed mainly in Northern part of China. After being collected from the original sites, the soils were air-dried and submitted to a standard procedure involving pre-sieving through a $4.75 \mathrm{~mm}$ aperture square-hole sieve to remove coarse rock and organic debris. The soils properties (Table 1), including particle-size composition, soil water content (SWC), bulk density (BD), organic matter (OM), $\mathrm{pH}$ and the cation exchange capacity (CEC) were measured using procedures outlined in the test method for the Examination of Soil Physical and Chemical Properties (ISSCAS, 1997). The sediment-bound available nitrogen (AN) concentration was determined with the persulfate digestion technique (Sollins et al., 1999), and the sediment-bound available phosphorus (AP) concentration was measured using the acid-extracted molybdenum colorimetric method with a $\mathrm{HCl}-\mathrm{NH} 4 \mathrm{~F}$ digestion (Olsen and Dean, 1965). For each soil, all measurements had two replicates.

\section{Soil flume preparation}

The soil flumes were structured with metal sheets and had the following dimensions: $2.0 \mathrm{~m}$ length $\times 0.75 \mathrm{~m}$ width $\times 0.5 \mathrm{~m}$ height. The structure had the slope adjusting screws allowing the control of the flume slope. Surface runoff and drainage water were collected at the end of the flume (Fig. 1). For the soil flume preparation, the bottom $0.02-0.03 \mathrm{~m}$ thick layer, the drain bed, in which the perforated drains were located, consisted of very fine sand to facilitate drainage. Then the soil was uniformly spread over the surface layer of the flume bed, followed by tamping with a wooden block, then by scraping the surface to a uniform thickness of $0.4 \mathrm{~m}$ (Romkens et al., 2001).

\section{Design of rainfall experiment}

The rainfall simulator was used to generate precipitation with varying intensities, which consists of three groups of oscillating TSPT-X type nozzles. The rainfall simulator were designed with a 3-nozzle unit, the characteristics is similar to the multiple-intensity rainfall simulator described by Romkens et al. (2001). In this experiment, eight simulated rainfalls were applied on the flume with two rainfall intensities, 60 or $120 \mathrm{~mm} \mathrm{~h}^{-1}$, and every rainfall intensity used two slopes(10\% and $20 \%)$ for each soil (Burozems and Cinnamon). On each soil flume, rainfall simulation events were conducted with 40-minute duration. Prior to each simulation, the soil water content in the soil flume was adjusted to the same levels of soil samples through operating the simulator at low rainfall intensities.

Surface runoff was collected using a runoff trough with a plate lip inserted into the soil, and discharge was monitored and sampled at the end of the flume every five minutes. The sediment was deposited in the pails

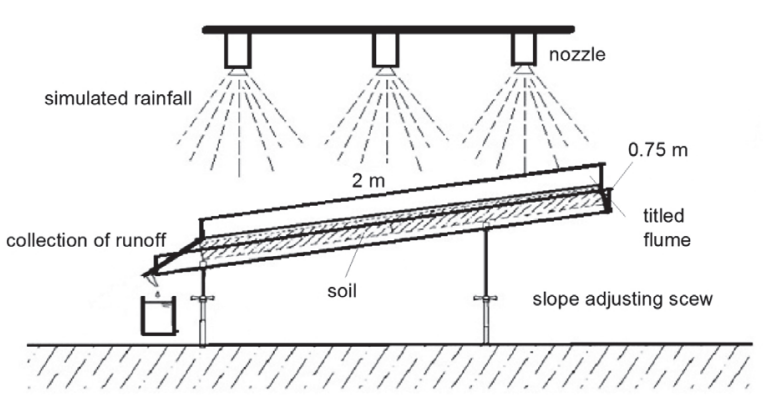

Fig. 1. Schematic map of the rainfall simulation.

Table 1. Mechanical composition, bulk density (BD), soil water content (SWC), pH, organic matter (OM), cation exchange capacity (CEC), for two soil samples collected from the study area

\begin{tabular}{|c|c|c|c|c|c|c|c|c|c|}
\hline \multirow[b]{2}{*}{ Soil Type } & \multicolumn{4}{|c|}{ Mechanical composition (\%) } & \multirow[b]{2}{*}{$\begin{array}{c}\mathrm{BD} \\
\left(\mathrm{g} \mathrm{cm}^{-3}\right)\end{array}$} & \multirow[b]{2}{*}{$\begin{array}{l}\text { SWC } \\
(\%)\end{array}$} & \multirow[b]{2}{*}{$\mathrm{pH}$} & \multirow[b]{2}{*}{$\begin{array}{c}\mathrm{OM} \\
\left(\mathrm{g} \mathrm{kg}^{-1}\right)\end{array}$} & \multirow[b]{2}{*}{$\begin{array}{c}\mathrm{CEC} \\
\left(\mathrm{cmol} \mathrm{g}^{-1}\right)\end{array}$} \\
\hline & $>0.1 \mathrm{~mm}$ & $\begin{array}{c}0.1-0.05 \\
\mathrm{~mm}\end{array}$ & $\begin{array}{c}0.05-0.01 \\
\mathrm{~mm}\end{array}$ & $\begin{array}{c}<0.01 \\
\mathrm{~mm}\end{array}$ & & & & & \\
\hline Burozems & 45.3 & 31.40 & 19.94 & 3.32 & 1.32 & 3.68 & 6.7 & 8.66 & 21.4 \\
\hline Cinnamon & 9.05 & 56.97 & 24.98 & 8.99 & 1.65 & 5.77 & 6.5 & 10.22 & 78.2 \\
\hline
\end{tabular}


after more than $24 \mathrm{~h}$ sedimentation, then air-dried and weighed. All the samples were taken at the five minutes. intervals. Immediately after the sample collection, the water sample was analyzed for available nitrogen (AN) and available phosphorus (AP). The AN and AP concentrations were analyzed every $10 \mathrm{~min}$ in the runoff and sediment samples by mixing two consecutive samples. Total surface runoff and soil loss of each simulated rainfall event were then calculated.

\section{Data analysis}

In this study, the soil erodibility was derived from the following linear regression equation which is widely used in many studies (Huang and Bradford, 1993; Pan and Shangguan, 2006):

$$
q_{s}=a q_{r}+b
$$

where $q_{s}$ was the sediment yield rate $\left(\mathrm{g} \mathrm{m}^{-2} \mathrm{~min}^{-1}\right), q_{r}$ was the runoff rate $\left(\mathrm{mm} \mathrm{min}^{-1}\right), a$ and $b$ were regression coefficients ( $a$ : $\mathrm{g} \mathrm{m}^{-2} \mathrm{~mm}^{-1}$; b: $g \mathrm{~m}^{-2} \mathrm{~min}^{-1}$ ), $a$ was best described soil erodibility.

Paired t test and Least Significant Difference (LSD) multiple-comparison test were used to identify statisti- call difference among treatments. ANOVA methods were used to analyze the impact of different soil samples on the variables. The SPSS 11.0 were used to perform all these analyses. Principal Components Analysis (PCA) method was used to determine the relationship between soil erodibility, nutrient losses and soil properties on $\mathrm{R}$ statistical software (R Development Core Team, 2011).

\section{RESULT ANALYSIS AND DISCUSSIONS}

\section{Changes in soil properties during the experiment}

The two original soil properties (Table 1) had distinctly different particle size composition. The coarse particles fraction $(>0.1 \mathrm{~mm}$ ) of Burozems accounted for $45.33 \%$ as compared to $9.05 \%$ of Cinnamon. However, finer particles fraction $(<0.0 .1 \mathrm{~mm})$ for Cinnamon soil (24.98\%) were considerably more than the value for Burozems soil (19.94\%). OM, CEC, BD, and SWC in the Cinnamon were greater than those in the Burozems, respectively. Table 2 showed the change of soil physical and chemical properties after the rainfall simulation. The BD increased in most soil samples due to the effects of raindrop compaction.

Table 2. Mechanical composition, bulk density (BD), soil water content (SWC), pH, organic matter (OM), cation exchange capacity (CEC), for two soil samples after rainfall simulation experiments

\begin{tabular}{|c|c|c|c|c|c|c|c|}
\hline \multicolumn{3}{|c|}{ Different treatments } & \multirow{2}{*}{$\begin{array}{c}\mathrm{BD} \\
\left(\mathrm{g} \mathrm{cm}^{-3}\right)\end{array}$} & \multirow{2}{*}{$\begin{array}{l}\text { SWC } \\
(\%)\end{array}$} & \multirow[b]{2}{*}{$\mathrm{pH}$} & \multirow{2}{*}{$\begin{array}{c}\mathrm{OM} \\
\left(\mathrm{g} \mathrm{kg}^{-1}\right)\end{array}$} & \multirow{2}{*}{$\begin{array}{c}\text { CEC } \\
\left(\mathrm{cmol} \mathrm{g}^{-1}\right)\end{array}$} \\
\hline Soil type & $\begin{array}{l}\text { Rainfall intensity } \\
\qquad\left(\mathrm{mm} \mathrm{h}^{-1}\right)\end{array}$ & Slope & & & & & \\
\hline \multirow[t]{4}{*}{ Burozems } & 60 & $10 \%$ & 1.43 & 37.0 & 7.4 & 7.52 & 27.1 \\
\hline & & $20 \%$ & 1.37 & 31.3 & 6.4 & 8.05 & 32.5 \\
\hline & 120 & $10 \%$ & 1.37 & 33.3 & 7.4 & 6.12 & 26.2 \\
\hline & & $20 \%$ & 1.39 & 30.9 & 6.1 & 7.44 & 29.3 \\
\hline \multirow[t]{4}{*}{ Cinnamon } & 60 & $10 \%$ & 1.76 & 37.7 & 5.6 & 9.83 & 79.8 \\
\hline & & $20 \%$ & 1.84 & 37.6 & 6.5 & 9.16 & 84.1 \\
\hline & 120 & $10 \%$ & 1.86 & 33.1 & 5.5 & 7.89 & 59.1 \\
\hline & & $20 \%$ & 1.42 & 37.0 & 7.4 & 8.93 & 43.7 \\
\hline
\end{tabular}

Table 3. The runoff rate and total runoff for the two soils under different treatments (soil, rainfall intensity and slope)

\begin{tabular}{|c|c|c|c|c|c|c|c|c|c|c|c|}
\hline \multicolumn{3}{|c|}{ Different treatments } & \multicolumn{8}{|c|}{$\begin{array}{c}\mathrm{Q} \\
\left(\mathrm{mm} \min ^{-1}\right)\end{array}$} & \multirow{2}{*}{$\begin{array}{l}\text { Total } \\
\text { runoff } \\
(\mathrm{mm})\end{array}$} \\
\hline Soil type & $\begin{array}{l}\text { Rainfall } \\
\text { intensity } \\
\left(\mathrm{mm} \mathrm{h}^{-1}\right)\end{array}$ & Slope & $\begin{array}{l}\text { after } \\
5 \text { min }\end{array}$ & $\begin{array}{c}\text { after } \\
10 \mathrm{~min}\end{array}$ & $\begin{array}{c}\text { after } \\
15 \text { min }\end{array}$ & $\begin{array}{l}\text { after } 20 \\
\text { min }\end{array}$ & $\begin{array}{c}\text { after } \\
25 \text { min }\end{array}$ & $\begin{array}{c}\text { after } \\
30 \mathrm{~min}\end{array}$ & $\begin{array}{c}\text { after } \\
35 \text { min }\end{array}$ & $\begin{array}{c}\text { after } \\
40 \mathrm{~min}\end{array}$ & \\
\hline \multirow[t]{4}{*}{ Burozems } & 60 & $10 \%$ & 0.27 & 0.27 & 0.29 & 0.41 & 0.40 & 0.48 & 0.72 & 0.79 & 1.81 \\
\hline & & $20 \%$ & 0.48 & 0.53 & 0.59 & 0.63 & 0.75 & 0.80 & 0.89 & 0.99 & 2.83 \\
\hline & 120 & $10 \%$ & 0.53 & 0.55 & 0.64 & 0.64 & 0.88 & 0.77 & 1.04 & 0.93 & 2.99 \\
\hline & & $20 \%$ & 0.55 & 0.56 & 0.71 & 0.95 & 0.92 & 1.03 & 1.08 & 1.13 & 3.46 \\
\hline \multirow[t]{4}{*}{ Cinnamon } & 60 & $10 \%$ & 0.50 & 0.44 & 0.49 & 0.67 & 0.89 & 0.89 & 0.96 & 0.99 & 2.92 \\
\hline & & $20 \%$ & 0.48 & 0.56 & 0.77 & 0.73 & 0.96 & 0.99 & 1.01 & 1.07 & 3.29 \\
\hline & 120 & $10 \%$ & 0.64 & 0.63 & 0.65 & 0.73 & 1.08 & 1.32 & 1.24 & 1.12 & 3.71 \\
\hline & & $20 \%$ & 0.67 & 0.69 & 0.96 & 1.04 & 1.23 & 2.00 & 1.91 & 2.03 & 5.26 \\
\hline
\end{tabular}


The SWC increased significantly in all of the soil samples but changed slightly among all the treatments, which indicated that the difference of slope steepness and rainfall intensity had no distinct influence on the SWC due to the sufficient soil saturation. The OM in the two soil samples decreased in different extent. The maximum decreased amount (40\%) occurred with a rainfall intensity of $120 \mathrm{~mm} \mathrm{~h}^{-1}$ and a slope of $10 \%$. The OM in the Burozems and Cinnanon were averagely (for each treatment) reduced to $15.9 \%$ and $12.4 \%$. There were no significant changes in the $\mathrm{pH}$ and $\mathrm{CEC}$ with different rainfall intensities and slopes.

\section{Runoff, soil loss and soil erodibility}

Table 3 showed the different runoff rate $(Q)$ variation from the two selected soils. The runoff rate increased gradually with time. The runoff rate and total runoff of Cinnamon was significantly higher than that of Burozems.
Runoff rate of Cinnamon increased sharply during the onset of runoff and slowed down gradually. It indicated that the runoff rates from all of the Cinnamon soil treatments reached the steady state before the treatment was over. For the Burozems, the rate gently increased. In comparison, the Burozems particles were coarser than the Cinnamon particles, which means that the Burozems had higher soil infiltration capacity. Therefore, the Burozems had less runoff than the Cinnamon. However, the runoff rate was significantly increased as the rainfall intensity and slope rising up. Our result was consistent with other studies (Helming et al., 1993; Romkens et al., 1986, 2001) in increasing rainfall intensity and slope increasing runoff rate. The runoff rate of Burozems was low in the treatments with rainfall intensity of $60 \mathrm{~mm} \mathrm{~h}^{-1}$ and slope of $10 \%$ ranged from $0.26 \mathrm{~mm} \mathrm{~min}^{-1}$ to $0.78 \mathrm{~mm}$ min $^{-1}$ as compared to other treatments ranged from $0.48 \mathrm{~mm} \mathrm{~min}^{-1}$ to $2.03 \mathrm{~mm} \mathrm{~min}^{-1}$. It might be because

Table 4. Sediment yield rate $(S)$ and total soil loss for the two soils under different treatments (soil, rainfall intensity and slope)

\begin{tabular}{|c|c|c|c|c|c|c|c|c|c|c|c|}
\hline \multicolumn{3}{|c|}{ Different treatments } & \multicolumn{8}{|c|}{$\begin{array}{c}S \\
\left(\mathrm{~g} \mathrm{~min}^{-1}\right) \\
\end{array}$} & \multirow{2}{*}{$\begin{array}{c}\text { Total soil } \\
\text { loss } \\
\text { (g) }\end{array}$} \\
\hline Soil type & $\begin{array}{c}\text { Rainfall } \\
\text { intensity } \\
\left(\mathrm{mm} \mathrm{h}^{-1}\right)\end{array}$ & Slope & $\begin{array}{l}\text { after } \\
5 \text { min }\end{array}$ & $\begin{array}{c}\text { after } \\
10 \text { min }\end{array}$ & $\begin{array}{c}\text { after } \\
15 \text { min }\end{array}$ & $\begin{array}{c}\text { after } \\
20 \text { min }\end{array}$ & $\begin{array}{c}\text { after } \\
25 \text { min }\end{array}$ & $\begin{array}{l}\text { after } \\
30 \text { min }\end{array}$ & $\begin{array}{c}\text { after } \\
35 \text { min }\end{array}$ & $\begin{array}{c}\text { after } \\
40 \text { min }\end{array}$ & \\
\hline \multirow[t]{4}{*}{ Burozems } & 60 & $10 \%$ & 2.62 & 3.53 & 3.37 & 1.63 & 2.26 & 2.35 & 1.98 & 1.53 & 144.43 \\
\hline & & $20 \%$ & 4.47 & 5.03 & 5.43 & 6.49 & 7.33 & 11.10 & 9.53 & 8.95 & 437.41 \\
\hline & 120 & $10 \%$ & 8.07 & 2.77 & 6.92 & 6.60 & 5.78 & 6.13 & 7.87 & 9.24 & 400.22 \\
\hline & & $20 \%$ & 7.80 & 8.67 & 8.52 & 8.69 & 7.41 & 11.61 & 11.28 & 13.04 & 577.74 \\
\hline \multirow[t]{4}{*}{ Cinnamon } & 60 & $10 \%$ & 5.56 & 3.79 & 5.77 & 11.01 & 20.61 & 19.28 & 21.34 & 21.13 & 813.67 \\
\hline & & $20 \%$ & 5.28 & 5.57 & 12.69 & 16.98 & 25.68 & 33.69 & 38.72 & 32.48 & 1283.04 \\
\hline & 120 & $10 \%$ & 2.92 & 5.72 & 17.13 & 19.48 & 19.23 & 17.66 & 19.48 & 19.31 & 906.89 \\
\hline & & $20 \%$ & 5.58 & 6.86 & 12.53 & 18.59 & 22.46 & 38.96 & 32.88 & 43.83 & 1362.60 \\
\hline
\end{tabular}

Table 5. The slope (a), intercept (b) and coefficient of determination $\left(\mathrm{R}^{2}\right)$ of linear regression of sediment yield rate $\left(q_{s}\right)$ and runoff rate $\left(q_{r}\right)\left(q_{s}=a q_{r}+b\right)$ for the two soils

\begin{tabular}{|c|c|c|c|c|c|}
\hline \multicolumn{3}{|c|}{ Different treatments } & \multirow[b]{2}{*}{$a$} & \multirow[b]{2}{*}{$b$} & \multirow[b]{2}{*}{$R^{2}$} \\
\hline Soil type & $\begin{array}{l}\text { Rainfall intensity } \\
\quad\left(\mathrm{mm} \mathrm{h}^{-1}\right)\end{array}$ & Slope & & & \\
\hline \multirow[t]{5}{*}{ Burozems } & \multirow[t]{2}{*}{60} & $10 \%$ & -2.73 & 3.65 & 0.895 \\
\hline & & $20 \%$ & 11.32 & -0.71 & 0.875 \\
\hline & \multirow[t]{2}{*}{120} & $10 \%$ & 4.68 & 3.16 & 0.622 \\
\hline & & $20 \%$ & 6.54 & 3.97 & 0.725 \\
\hline & \multicolumn{2}{|c|}{ Total } & 9.87 & -0.32 & $0.614^{* *}$ \\
\hline \multirow[t]{5}{*}{ Cinnamon } & \multirow[t]{2}{*}{60} & $10 \%$ & 33.86 & -11.17 & $0.995^{* *}$ \\
\hline & & $20 \%$ & 56.12 & -24.79 & $0.980^{* *}$ \\
\hline & \multirow[t]{2}{*}{120} & $10 \%$ & 14.59 & 1.59 & 0.398 \\
\hline & & $20 \%$ & 24.71 & -9.80 & $0.968 * *$ \\
\hline & \multicolumn{2}{|c|}{ Total } & 22.48 & -3.14 & $0.680 * *$ \\
\hline
\end{tabular}

$* * \mathrm{p}<0.01, * \mathrm{p}<0.05$ 
each contributing factor (slope of $20 \%$, rainfall intensity of $120 \mathrm{~mm} \mathrm{~h}^{-1}$ ) was effective in increasing runoff.

The sediment yield rate $(S)$ also varied with time (Table 4) for all of the treatments. Similar to the characteristic of runoff rate, the Cinnamon had a much higher $S$ than the Burozems. In addition, the $S$ of Cinnamon initially increased linearly and reached steady state around 25 minutes. The erosion characteristics of Burozems were distinctly different from those of Cinnamon. The $S$ of Burozems varied negatively with time and was less than the $S$ of Cinnamon attributing to the finer particles, which were easily transported by runoff. It was obvious that the soil loss increased greater with increasing slope than with increasing rainfall intensity. The total soil loss for both the Burozems and the Cinnamon in the treatments with a rainfall intensity of $60 \mathrm{~mm} \mathrm{~h}^{-1}$ and a slope of $20 \%$ exceeded those in the treatments with a rainfall intensity of $120 \mathrm{~mm} \mathrm{~h}^{-1}$ and a slope of $10 \%$, and even approached to that in the treatments with a rainfall intensity of $120 \mathrm{~mm} \mathrm{~h}^{-1}$ and a slope of $20 \%$. These results showed that the increasing gravity (10\% to $20 \%$ ) had stronger influence in increasing soil loss than the increasing rainfall erosive force $\left(60 \mathrm{~mm} \mathrm{~h}^{-1}\right.$ to $\left.120 \mathrm{~mm} \mathrm{~h}^{-1}\right)$.

The indicator of soil erodibility established by the relationship between sediment yield rate and runoff rate has been widely regarded as the slope of a linear function under net detachment conditions (Pan and Shangguan, 2006; Wang et al., 2013). Sediment yield rate $\left(q_{s}\right)$ was a function of runoff rate $\left(q_{w}\right)$ for each treatment and the relationship could be well fitted by the linear equation (1) in the study (Table 5). The absolute value of slope $a$ could describe the soil erodibility, which ranged from $-.2 .73 \mathrm{~g} \mathrm{~m}^{-2} \mathrm{~mm}^{-1}$ to $11.32 \mathrm{~g} \mathrm{~m}^{-2} \mathrm{~mm}^{-1}$ for Burozems, and $14.59 \mathrm{~g} \mathrm{~m}^{-2} \mathrm{~mm}^{-1}$ to $56.12 \mathrm{~g} \mathrm{~m}^{-2} \mathrm{~mm}^{-1}$ for Cinnamon. It means that the soil erodibility of the Cinnamon was greater than that of the Burozems corresponding to the relationship of runoff and soil loss between the two soils. The $q_{\mathrm{s}}$ in the Burozems treatments with rainfall intensity of $60 \mathrm{~mm} \mathrm{~h}^{-1}$ and a slope of $10 \%$ was negatively correlated with the runoff rate. Pan and Shangguan (2006) also observed a negative relationship between these two variables in bare soil samples when the runoff rate was less than $1 \mathrm{~mm} \mathrm{~min}^{-1}$. For both soils, the soil erodibility indicator was positively correlated with the slope and negatively correlated with the rainfall intensity. The increasing value with increasing slope was similar to the results observed by Huang and Bradford (1993). This result may be associated with decrease in aggregation ability due to increase in soil gravitational erosive force.

\section{Sediment-bound nutrient losses}

Fig. 2 and Fig. 3 displayed the sediment-bound AN and AP loss rate as a function of time. The trend of sediment-bound AN and AP loss rate varied similarly with the sediment yield rate $(S)$. The nutrient losses for the Cinnamon significantly increased with high $S$, while the nutrient losses for the Burozems increased gently with low $S$. For the Cinnamon, the sediment-bound AN loss rate reached to steady-state after about 20 mins for each treatment. The result confirmed the theory that the nutrient loss is influenced by load capacity, and once the nutrient load capacity exceeds rate of nutrient desorption, the nutrient losses becomes nearly constant (Gilley et $a l ., 2012)$. The averaged sediment-bound AN loss rate were $2.34 \mathrm{mg} \mathrm{m}^{-2} \mathrm{~min}^{-1}$ (Burozems) and $20.43 \mathrm{mg}$ $\mathrm{m}^{-2} \mathrm{~min}^{-1}$ (Cinnamon), and the averaged sediment-bound $\mathrm{AP}$ loss rate were $0.03 \mathrm{mg} \mathrm{m}^{-2} \mathrm{~min}^{-1}$ (Burozems) and $0.20 \mathrm{mg} \mathrm{m}^{-2} \mathrm{~min}^{-1}$ (Cinnamon). If the sediment-bound available nutrient mobility should be expressed as the nutrient loss rate, the order for the mobility is $\mathrm{AN}>\mathrm{AP}$, and the AN loss rate were two orders of magnitude greater than the AP loss rate. The results were in agreement with many previous studies (Berghe and Boodt, 1978; Wu et al., 2012). A positive linear function (Fig. 4, 5 and Table 6) should best describe the relationship between nutrient losses and $S$ for each treatment. The results were also found by Zhang et al. (2011) who observed the relationship under different rainfall intensity and vegetation coverage. For a specific soil type, the slopes (absolute value) of regression are almost equal for all treatments and could be regressed as a single equation ("total" in Table 6). The result implied that the

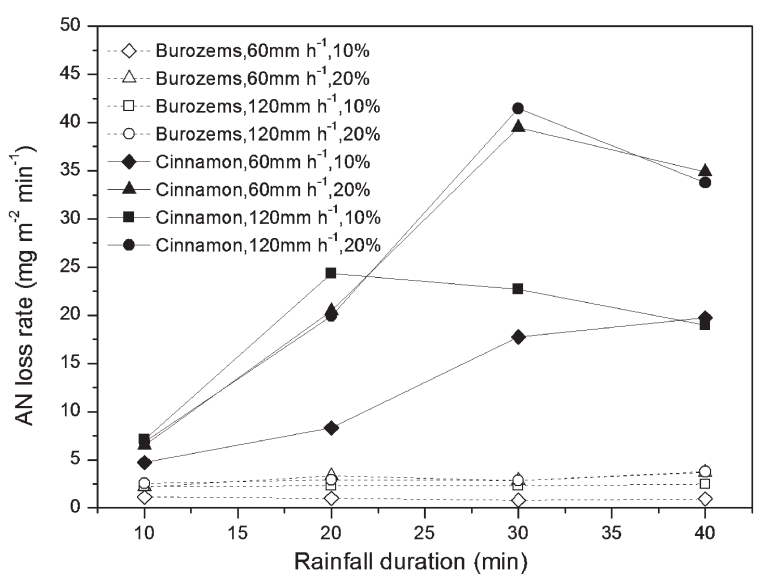

Fig. 2. Sediment-bound available nitrogen (AN) loss rate as a function of time for the two soils under different treatments (soil, rainfall intensity, slope).

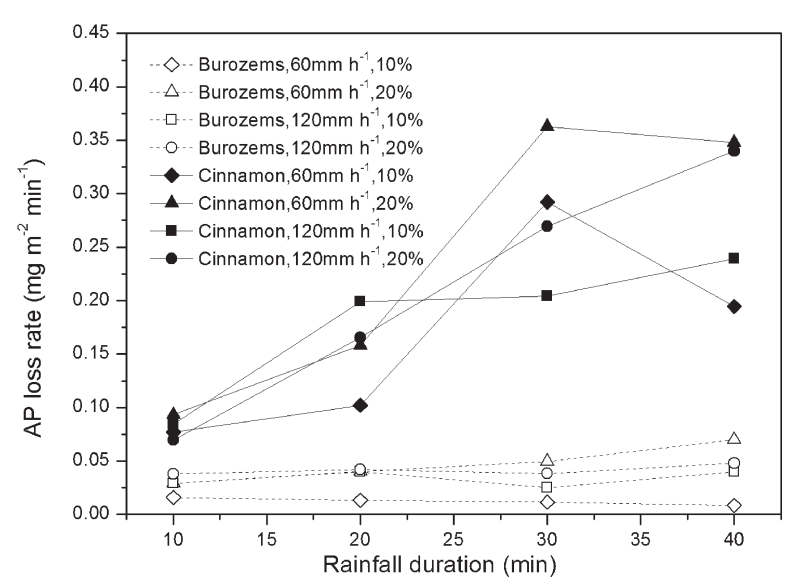

Fig. 3. Sediment-bound available phosphorus (AP) loss rate as a function of time for the two soils under different treatments (soil, rainfall intensity, slope). 


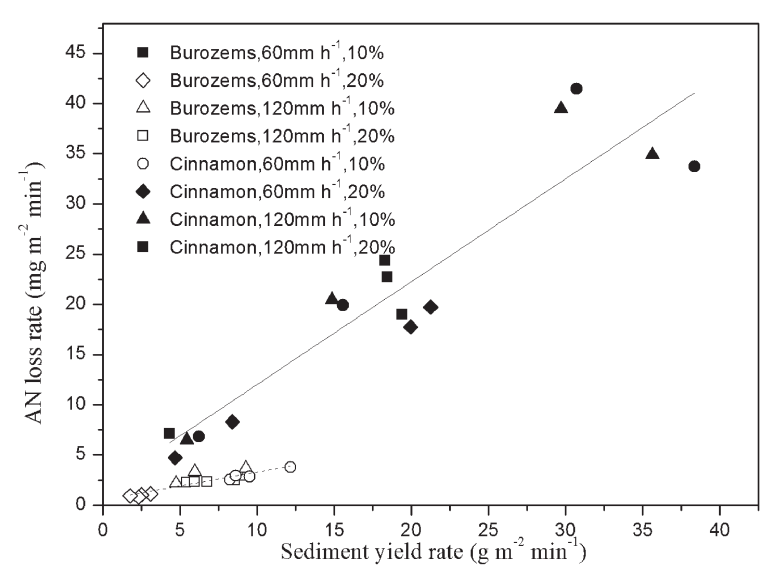

Fig. 4. Sediment-bound available nitrogen (AN) loss rate as a function of sediment yield rate for both soils under different treatments (soil, rainfall intensity, slope).

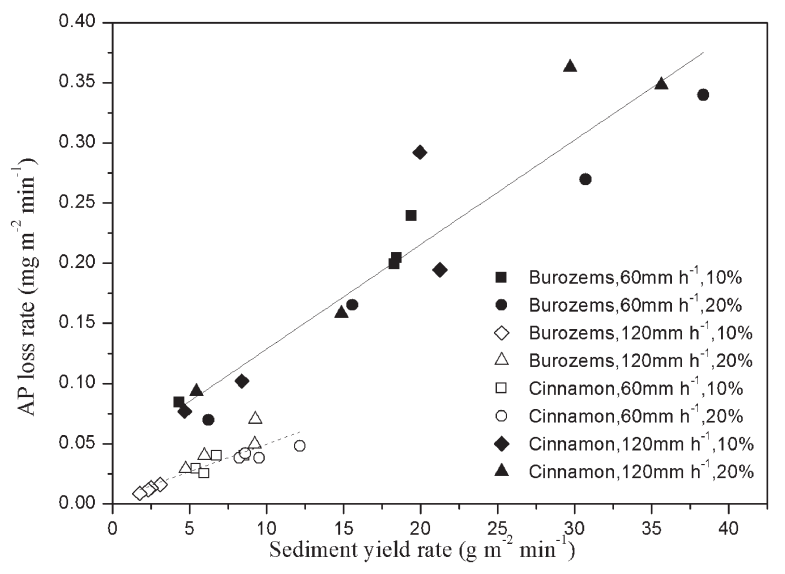

Fig. 5. Sediment-bound available phosphorus (AP) loss rate as a function of sediment yield rate for both soils under different treatments (soil, rainfall intensity, slope). contributing factors (slope and rainfall intensity) had no impact on the relationship between sediment-bound available nutrient losses and $S$. Because the $S$ had a similar trend with runoff rate, there was a similar relationship (results not shown) between runoff rate and sedimentbound nutrient losses.

\section{Correlation among soil erodibility, soil properties and sediment-bound available nutrient losses}

Principal components analysis (PCA) method showed that differences in soil treatments (slope and rainfall intensity) were captured largely by the first and second

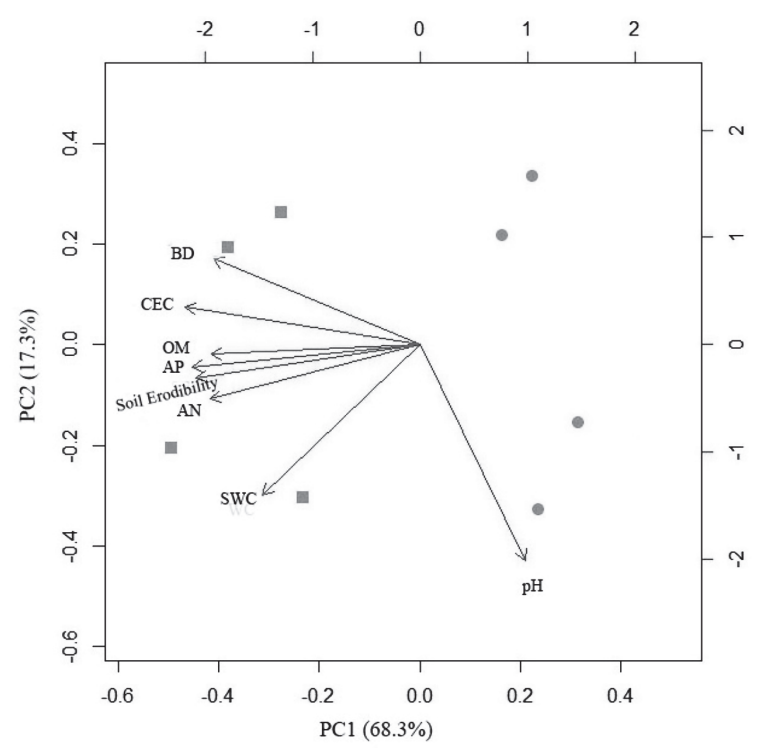

Fig. 6. Principal component analysis (PCA) of soil erodibility, soil properties and sediment-bound nutrient losses (AN and AP). The soil properties represented the values after rainfall simulation in the soil samples for each treatment including bulk desity (BD), cation exchange capacity (CEC), soil water content (SWC), $\mathrm{pH}$ and soil organic matter (OM). Geometric shapes indicate two soil types (Burozems: circle; Cinnamon: square).

Table 6. Relationship between sediment-bound nutrient loss rate (AN: available nitrogen; AP: available phosphorus) and sediment yield rate for the two soils under different treatments.

\begin{tabular}{|c|c|c|c|c|c|c|}
\hline \multicolumn{3}{|c|}{ Different treatments } & \multicolumn{2}{|c|}{$\begin{array}{l}\text { Sediment-bound AN loss rate }(y) \\
\text { and sediment yield rate }(x)\end{array}$} & \multicolumn{2}{|c|}{$\begin{array}{l}\text { Sediment-bound AP loss rate }(y) \\
\text { and sediment yield rate }(x)\end{array}$} \\
\hline Soil type & $\begin{array}{l}\text { Rainfall intensity } \\
\left(\mathrm{mm} \mathrm{h}^{-1}\right)\end{array}$ & Slope & Equation & $R^{2}$ & Equation & $R^{2}$ \\
\hline \multirow[t]{5}{*}{ Burozems } & 60 & $10 \%$ & $y=0.166 x+0.577$ & 0.429 & $y=0.005 x-0.001$ & $0.991 * *$ \\
\hline & & $20 \%$ & $y=0.171 x+1.767$ & 0.361 & $y=0.006 x-0.001$ & 0.767 \\
\hline & 120 & $10 \%$ & $y=0.063 x+1.923$ & 0.863 & $y=0.004 x+0.004$ & 0.598 \\
\hline & & $20 \%$ & $y=0.283 x+0.299$ & $0.923^{*}$ & $y=0.002 x+0.020$ & 0.722 \\
\hline & Tot & & $y=0.276 x+0.542$ & $0.808 * *$ & $y=0.004 x+0.003$ & $0.746^{* * *}$ \\
\hline \multirow[t]{5}{*}{ Cinnamon } & 60 & $10 \%$ & $y=0.876 x+0.747$ & $0.997 * *$ & $y=0.010 x+0.024$ & 0.780 \\
\hline & & $20 \%$ & $y=1.029 x+3.314$ & $0.900 *$ & $y=0.009 x+0.036$ & $0.944^{*}$ \\
\hline & 120 & $10 \%$ & $y=1.009 x+3.037$ & 0.877 & $y=0.009 x+0.043$ & $0.960 *$ \\
\hline & & $20 \%$ & $y=0.956 x+3.767$ & 0.823 & $y=0.008 x+0.026$ & $0.994 * *$ \\
\hline & Tot & & $y=1.024 x+1.798$ & $0.874 * *$ & $y=0.008 x+0.041$ & $0.896^{* *}$ \\
\hline
\end{tabular}


axis, which had the cumulative proportion of $86.6 \%$ for all variability between samples (Fig. 6). However, the soil erosion parameters were better related with the Cinnamon than with the Burozems, which was due to the slight change in soil erosion parameters of Burozems. The PCA results also indicated many significant relationships among the soil erosion parameters, soil erodibility, changed soil properties after rainfall simulation and sediment-bound available nutrient losses. The soil OM is significantly related to the calculated soil erodibility. Other researchers (Evans and Cook, 1986; Guerra, 1994) also found that the $\mathrm{OM}$ and the large amounts of water stable aggregates $(>0.5 \mathrm{~mm}$ ) played an important role in soil erodibility. The higher OM had higher cohesive forces, which held the soil particles within an aggregate regarded as an effective stress to the soil erodibility (Wuddivira et al., 2013). However, soil erodibility was not only controlled by the soil OM, but also by other soil properties (Ekwue, 1992; Yu et al., 2006). The effect of $\mathrm{BD}$ and CEC should have been weaker than the effect of OM. SMC and $\mathrm{pH}$ were not significantly related to soil erodibility. However this did not mean that the two factors had no relationship with soil erodibility. It may be due to the pre-disposal of the soil samples.

The sediment-bound AN and AP losses were the most significant factor associated with the calculated soil erodibility in this study. That is because that higher or lower soil erodibility resulted in corresponding runoff and soil loss, and the sediment-bound AN and AP losses were strongly related to runoff and sediment based on former analysis. Hence the soil erodibility indirectly influenced the sediment-bound AN and AP losses. Other literatures also found the nutrient losses affected soil erodibility (Zhang et al., 2011; Zhu et al., 2010). In general, the relationship between soil erodibility and nutrient losses in the soil erosion process is a result of combined interaction.

\section{CONCLUSIONS}

Rainfall simulation experiments with different treatments were designed to examine the soil erodibility and available nutrient losses at laboratory scale for two contrasting soils of China (Burozems and Cinnamon). The impacts of runoff, soil loss on the sediment-bound AN and AP losses, the relationship among soil erodibility, soil properties and the sediment-bound AN and AP losses were investigated in this study. The different soil erodibility of Burozems and Cinnamon accompanied with distinctively different soil erosion characteristic. The soil erodibility increased with the increase of slope and decreased with the increase of rainfall intensity. Linear regression showed that the sediment-bound AN and AP losses were mainly controlled by sediment, and there were no significant influence of slope and rainfall intensity on the relationship between these two variables. The PCA analysis results showed that the sediment-bound AN and AP losses were most significantly associated with soil erodibility as compared with other soil properties. The OM also had significant influence the soil erodibility.
Other soil properties (BD and CEC) should have weaker effect than the soil OM in the study. The study had a good evaluation on the role of soil erodibility related to the sediment-bound AN and AP losses and other soil erosion parameters.

\section{ACKNOWLEDGEMENTS}

This research is supported by the National Natural Science Foundation of China (Grant No. 91125015).

\section{REFERENCES}

Alberts, E. E., M. A. Nearing, M. A. Weltz, L. M. Risse, F. B. Pierson, X. C. Zhang, J. R. Laflen, and J. R. Simanton. 1995 Chapter 7: Soil Component. Technical Documentation WEPP. In USDA Water Erosion Prediction Project Hillslope and Watershed Model Documentation

Berghe, V., Den, C. H. and De Boodt, M. F. 1979 A laboratory rainfall simulator study for determining the nutrient erodibility of an oxisol. J. Sci. Food and Agri., 30(5): 532-539

Bryan, R. B. and De Ploey, J. 1983 Comparability of soil loss measurements with different laboratory rainfall simulators. Rainfall simulation, runoff and soil erosion, Catena Sup., 4: 33-56

Bowyer-Bower, T. A. S. and Burt, T. P. 1989 Rainfall simulators for investigating soil response to rainfall, Soil Technol., 2: 1-16

Coleman, D. C., Ingham, E. R., Hunt, H. W., Elliott, E. T., Reid, C. P. P. and Moore, J. C. 1990 Seasonal and faunal effects on decomposition in semiarid prairie, meadow and lodgepole pine forest. Pedobiologia, 34(3): 207-219

Ekwue, E. I. 1992 Effect of organic and fertilizer treatments on soil physical properties and erodibility. Soil and Till. Res. 22(34): 199-209

Evans R. and Cook, B. 1986 Soil erosion in Britain. The Journal of the Southeast England Soils Discussion Croup, 3: 28-58

Flanagan D. C. and Nearing M. A. 1995 USDA-Water Erosion Prediction project: Hillslope profile and watershed model documentation. NSERL Report No. 10. USDA-ARS National Soil Erosion Research Laboratory, West Lafayette, Ind.

Gilley, J. E., Vogel, J. R., Eigenberg, R. A., Marx, D. B., and Woodbury, B. L., 2012 Nutrient losses in runoff from feedlot surfaces as affected by unconsolidated surface materials, J. Soil Water Conserv., 67: 11-17

Guerra, A. 1994 The effect of organic matter content on soil erosion in simulated rainfall experiments in W. Sussex, UK. Soil use and manage., 10(2): 60-64

Helming, K., Roth, Ch. H., Wolf, R. and Diestel, H., 1993 Characterization of rainfall-microrelief interactions with runoff using parameters derived from digital elevation models (DEM's). Soil Technol, 6: 273-286

Huang, C. H., and Bradford, J. M., 1993 Analyses of Slope and Runoff Factors Based on the WEPP Erosion Model, Soil Sci. Soc. Am. J, 57: 1176-1183

Institute of Soil Science, Chinese Academy of Sciences (ISSCAS), 1997 Soil Physical and Chemical Analysis Method. Sciences and Technology Press of Shanghai, Shanghai

Meyer, L. D., 1988 Rainfall simulators for soil conservation research. In: Lal, R. (Ed.), Soil Erosion Research Methods. Soil and Water Conservation Society, Ankeny, IA, 75-95

Morgan, R. P. C., 2005 Soil Erosion and Conservation, Blackwell Publishing, Oxford

Olsen, S. R. and Dean, L. A., 1965 Phosphorus in: Methods of Soil Analysis, edited by: Black, C. A., American Society of Agronomy, Inc., Madison, Wisconsin, U.S.A., 1035-1049

Pan, C. Z., and Shangguan, Z. P., 2006 Runoff hydraulic characteristics and sediment generation in sloped grassplots under simulated rainfall conditions, J. Hydrol., 331:178-185

R Development Core Team, 2011 R: A Language and Environment for Statistical Computing. $\mathrm{R}$ Foundation for Statistical 
Computing, Vienna

Romkens, M. J. M., Baumhardt, R. L., Parlange, J. Y., Whisler, F. D., Parlange, M. B. and Prasad, S. N., 1986 Effect of rainfall characteristics on seal hydraulic conductance. In: Callebaut, F. Gabriels, D., De Boodt, M.(Eds), Assessment of Surface Sealing and Crusting. Flander Research Center for Soil Erosion and Soil Conservation, Ghent, pp. 228-235

Römkens, M. J., Helming, K., and Prasad, S. N. 2001 Soil erosion under different rainfall intensities, surface roughness, and soil water regimes. Catena, $\mathbf{4 6}(2)$ : 103-123

Römkens, M. J. M., Helming, K., and Prasad, S. N., 2002 Soil erosion under different rainfall intensities, surface roughness, and soil water regimes, Catena, 46: 103-123

Sheridan, G. J., Noske, P. J., Lane, P. N. and Sherwin, C. B. 2008 Using rainfall simulation and site measurements to predict annual interrill erodibility and phosphorus generation rates from unsealed forest roads: Validation against in-situ erosion measurements. Catena, 73(1): 49-62

Sollins P, Classman, C., Paul, E. A., Swanston, C., Lajtha, K., Heil, J. W. and Elliott, E. T. 1999 Soil carbon and nitrogen pools and fractions, in: Standard Soil Methods for Long-term Ecological Research, edited by: Robertson, G. P., Coleman, D. C., Bledsoe, C. S. and Sollins, P. Oxford University Press, New York, U.S.A, pp. 94-96

Wang, G. Q., Hapuarachchi, P., Ishidaira, H., Kiem, A., and Takeuchi, K., 2009 Estimation of soil erosion and sediment yield during individual rainstorms at catchment scale, Water Resour Manage., 23: 1447-1465

Wang, G. Q., Wu, B. B., Zhang L., Jiang H., and Xu Z. X., 2014 Role of soil erodibility in affecting available nitrogen and phosphorus losses under simulated rainfall, J. Hydro., 514: 180-191

Wischmeier W. H. and Smith D. D. 1978 Predicting rainfall erosion losses. USDA Agricultural Research Services Handbook 537. USDA, Washington, DC, pp. 57

Wuddivira, M. N., Stone, R. J. and Ekwue, E. I. 2013 Influence of cohesive and disruptive forces on strength and erodibility of tropical soils. Soil and Till. Res., 133: 40-48

Wu, X. Y., Zhang, L. P. and Yu, X. X. 2012 Impacts of surface runoff and sediment on nitrogen and phosphorus loss in red soil region of southern China, Environ. Earth Sci., 67: 1939-1949

Yu, D. S., Shi, X. Z. and Weindorf, D. C. 2006 Relationships between permeability and erodibility of cultivated acrisols and cambisols in subtropical China. Pedosphere, 16: 304-311

Zhang, G. H., Liu, G. B., Wang, G. L. and Wang, Y. X. 2011 Effects of vegetation cover and rainfall intensity on sediment-associated nitrogen and phosphorus losses and particle size composition on the Loess Plateau, J. Soil Water Conserv., 66 $92-100$

Zhu B. B., Li, Z. B., Li, P., Liu, G. B., and Xue, S. 2010 Soil erodibility, microbial biomass, and physical-chemical property changes during long-term natural vegetation restoration: a case study in the Loess Plateau, China, Ecol. Res., 25: 531-541 